\title{
Penerapan Metode Single Exponential Smoothing Untuk Analisa Peramalan Penjualan
}

\author{
Agustinus Budi Santoso ${ }^{1, *}$, Matheus Supriyanto Rumetna ${ }^{2}$, Kristy Isnaningtyas ${ }^{1}$ \\ ${ }^{1}$ Sistem Informasi, Universitas Sains Dan Teknologi Komputer, Semarang, Indonesia \\ ${ }^{2}$ Fakultas Ilmu Komputer, Universitas Victory Sorong, Sorong, Indonesia \\ Email: 1," agustinus.bs@ @stekom.ac.id, ${ }^{2}$ matheus.rumetna@gmail.com, ${ }^{3}$ kristyisna@gmail.co.id \\ Email Penulis Korespondensi: agustinus.bs@stekom.ac.id
}

\begin{abstract}
Abstrak-Apotik merupakan bagian dalam distribusi kategori penjualan dan pembelian obat. Permintaan obat menjadi titik poin dalam persebaran pelanggan terhadap obat. Karyawan bertindak mempersiapkan dan melakukan pencatatan order pembelian obat bulan berikutnya. Kegiatan mengurutkan data persediaan obat yang tersedia dan tidak tersedianya sering membutuhkan waktu yang lama. Metode Exponential Smoothing merupakan metode peramalan pada rata-rata bergerak dengan memberikan pembobotan yang mudah dianalisa. Data penjualan time series dengan peramalan metode Exponential Smoothing diharapkan mampu menangani persediaan yang optimal untuk kontrol persediaan stok obat. Penggunaan data 6 bulan terakhir sebagai data acuan pencatatan masa lalu untuk percobaan peramalan untuk 3 bulan kedepan. Percobaan dengan Alpha berbeda menguji ketepatan pada keadaan nyata. Hasil percobaan dengan alpa 0,3 mendekati nilai nyata pada peramalan 3 bulan kedepan.
\end{abstract}

Kata Kunci: Single Exponential Smoothing; Peramalan; Stok; Penjualan; Apotik

\begin{abstract}
Pharmacies are part of the distribution category of drug sales and purchases. The demand for drugs becomes a focal point in the distribution of customers to drugs. Employees act to prepare and record drug purchase orders for the following month. The activity of sorting the available and unavailability of drug supply data often takes a long time. Exponential smoothing method is a method of forecasting moving averages by providing easy-to-analyze weighting. Time series sales data with Exponential Smoothing forecasting method is expected to be able to handle optimal inventory for controlling drug stock inventory. The use of data for the last 6 months as reference data for recording the past for forecasting experiments for the next 3 months. Experiments with different Alpha tests for accuracy in real life. The results of the experiment with alpha 0.3 are close to the real value in forecasting the next 3 months.
\end{abstract}

Keywords: Single Exponential Smoothing; Forecasting; Stock; Sales; Pharmacy

\section{PENDAHULUAN}

Pemenuhan dalam pemerataan pemenuhan kesesuian stok obat merupakan salah satu bagian yang paling penting dalam suatu proses perilaku penjualan serta pembelian pada apotik. Inventory barang merupakan barang dagangan yang utama dalam perusahaan dagang [1] pada pelaku usaha menjadi keperluan penting bagi suatu perusahaan, berawal dari inventory maka pengelolaan stok barang gudang dan display menjadi titik poin penjualan kepada pelanggan [2] dan digunakan juga untuk keberlangsungan produksi [3]. Persediaan yang tinggi memungkinkan perusahaan memenuhi permintaan yang mendadak dalam jumlah yang memadai, tersebar merata dan harganya terjangkau oleh masyarakat [4]. Apotek Waras Wiris setiap bulan mengalami perubahan peningkatan dan penurunan transaksi penjualan. Karyawan harus menyiapkan dan merancang order pembelian obat bulan berikutnya. Kegiatan menyiapkan stok pembelian obat yang tersedia dan habis membutuhkan waktu relatif lebih lama apabila manual.

Kegiatan ini berdampak pada proses pendistribusian karena membuat ketidakpastian karyawan dalam memesan obat pada distributor, dan tidak terkontrolnya penjualan obat karena perencanaan yang kurang matang dan produktifitas karyawan dalam bekerja tidak optimal. Penyebab tidak optimal tersebut menjadikan pelanggan atau konsumen tidak mendapat permintaan yang diajukan ke Apotik. Karyawan wajib memberikan perencanaan aktif setiap akhir pre order terhadap pemasok obat. Penelitian sistem informasi berbentuk alat bantu peramalan yang merupakan penting dalam perencanaan yang lebih efektif dan efisien berdasarkan metode peramalan Exponential Smoothing [5].

Exponential Smoothing sering disebut juga Penghalusan Eksponensial, Metode Smoothing Exponential merupakan peramalan dengan teknik rata-rata bergerak dimana pembobotan data diberi bobot dengan sebuah fungsi exponential [6]. Exponential Smoothing merupakan salah satu metode peramalan rata-rata bergerak canggih, dan mudah digunakan [7]. Metode ini merupakan metode peramalan yang cukup baik untuk peramalan jangka panjang dan jangka menengah [8]. Metode ini merupakan metode yang menunjukkan penurunan pembobotan secara eksponensial terhadap nilai observasi [9]. Parameter metode penghalusan eksponential (Exponential Smoothing) dilambangkan dengan $\alpha$ (alpha). Gambaran tersebut digunakan untuk mengolah bagian karyawan karena dengan metode tersebut apotik dapat memprediksi langkah apa yang dilakukan dalam memenuhi permintaan konsumen. Ramalan tidak dapat menjawab sempurna atau 100\% dalam meramalkan data, karena masa depan merupakan ketidakpastian. Ketidakpastian tersebut dapat di uji dengan peramalan uji coba menggunakan alpha berbeda untuk mendapatkan hasil yang lebih menuju kenyataan hasil peramalan.

Program ini dapat meramalkan penjualan obat berdasarkan riwayat penjualan pada bulan-bulan sebelumnya (time series) yang merupakan suatu data pengamatan [10]. Data penjualan didapat dengan data historis pada bagian 
stock opname dan data penjualan. Dengan melihat data sebelumnya, maka membantu pengguna dalam mengambil suatu keputusan untuk menentukan melakukan pembelian obat. Data tersebut diolah dengan menggunakan alpha berbeda dan membandingkan alpha manakah yang lebih digunakan untuk meramalkan keadaan. Metode peramalan yang akan digunakan pada penelitian ini adalah Single Exponential Smoothing.

\section{METODOLOGI PENELITIAN}

Metode penelitian yang digunakan adalah Research and Development (R\&D), R\&D merupakan metode penelitian yang dilaksanakan guna menghasilkan produk tertentu, dan menguji keefektifan produk tersebut [11] .

Pemulusan Eksponensial (Exponential Smoothing) merupakan metode peramalan menggunakan rata-rata bergerak dengan pembobotan yang canggih, tetapi masih mudah digunakan. Metode peramalan menggunakan data history masa lalu yang sedikit atau tidak terlalu banyak. Model ini dapat diasumsikan bahwa data naik turun di sekitar nilai mean yang tetap, tanpa trend atau pola pertumbuhan konsisten, tanpa mengikuti pola atau tren [12] dengan menggunakan data masa lampau [13]. Rumus penghalusan exponential dapat ditunjukkan sebagai berikut:

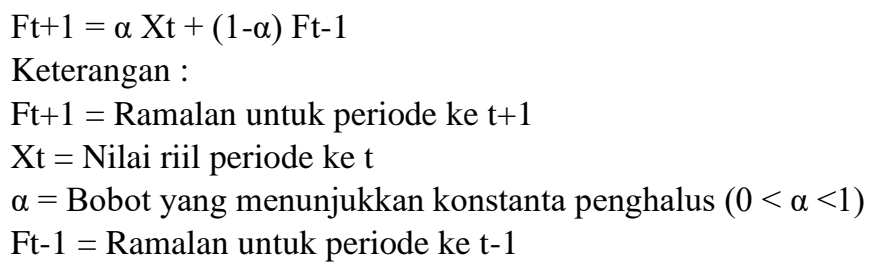

\subsection{Penelitian Resource and Development (R\&D)}

Metode penelitian yang digunakan adalah Research and Development (R\&D), R\&D merupakan metode penelitian yang digunakan untuk menghasilkan produk tertentu, dan menguji keefektifan produk tersebut [11].

Untuk dapat menghasilkan produk tertentu [14], digunakan penelitian yang bersifat analisis kebutuhan dan untuk menguji keefektifan produk tersebut supaya dapat berfungsi dengan baik di masyarakat luas, maka diperlukan penelitian untuk menguji keefektifan produk. Research and Development digunakan untuk mengembangkan dan memvalidasi produk-produk persediaan. Penelitian dan pengembangan ada 3 tahap yaitu fase penelitian pendahuluan, fase pengembangan prototype, fase penilaian [15] dan terdiri dari 10 langkah.

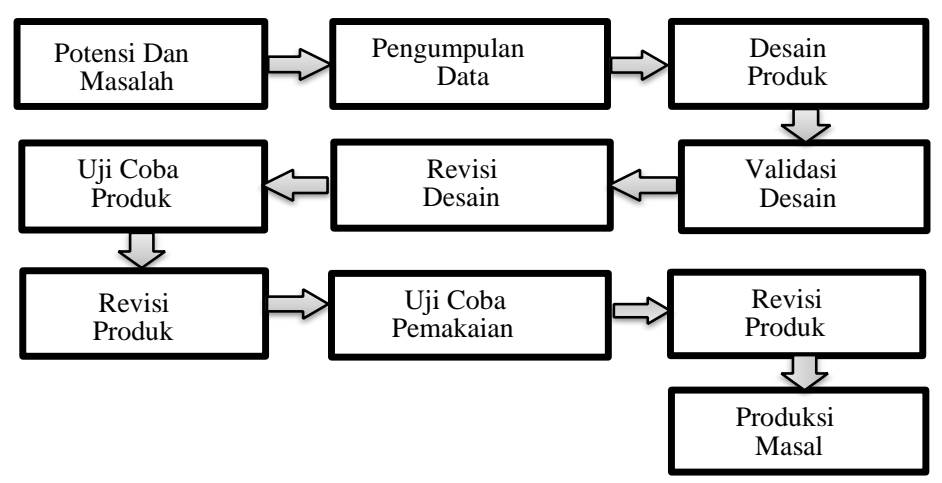

Gambar 1. Alur Penelitian Research and development

\section{HASIL DAN PEMBAHASAN}

Berdasarkan data yang sudah ada, digunakan untuk perhitungan Metode Single Exponential Smoothing. Untuk mendapatkan hasil pembelian barang di bulan berikutnya. Apotek Waras Wiris diharapkan dapat terus meningkat keuntungan dengan menyediakan obat sesuai dengan permintaan pasar. Namun pada laporan penjualan obat pada Apotek Waras Wiris terdapat bahwa kebutuhan akan konsumsi obat tidak signifikan, terjadi peningkatan maupun penurunan dalam penjualan obat dari bulan sebelumnya. Data yang digunakan adalah data penjualan obat dari bulan Januari 2020 sampai Juni 2020. Data input dan output dihubungkan dengan satu fungsi yang akan diolah dengan menggunakan Metode Single Exponential smoothing melalui tahap pembelajaran dan tahap peramalan, sehingga diharapkan dapat menentukan berapa banyak obat yang terjual pada bulan berikutnya oleh pihak apotek, dengan adanya sistem ini diharapkan dapat menghasilkan peramalan yang optimal.

Perbandingan dengan sebelumnya pada penelitian Sofiana, Exponential Smoothing digunakan untuk peramalan penambahan jumlah penumpang pesawat. Peramalan ini ditujukan juga untuk perbandingan dengan menggunakan Holt Winter's dengan Event Base penelitian ini menghasilkan bahwa peningkatan terjadi sejak 2013 sampai 2019 dengan pengujian algoritma Exponential Smoothing [16]. Penelitian lain dari Aris Purwanto mengenai sistem 
JURNAL MEDIA INFORMATIKA BUDIDARMA

Volume 5, Nomor 2, April 2021, Page 756-761

ISSN 2614-5278 (media cetak), ISSN 2548-8368 (media online)

Available Online at https://ejurnal.stmik-budidarma.ac.id/index.php/mib DOI 10.30865/mib.v5i2.2951

peramalan produksi jagung dimana mengguankan exponential smoothing untuk menguji pola trend dan pengujian pemulusan dengan parameter 0,4 dengan menghasilkan eror pada MAPE lebih kecil yaitu 9,38\% [17]

Tabel 1. Penjualan Obat Apotek Waras Wiris Periode Januari 2020 - Juni 2020

\begin{tabular}{lcccccc}
\hline \multicolumn{1}{c}{ Nama } & Januari & Februari & Maret & April & Mei & Juni \\
\hline Ultraflu & 50 & 125 & 100 & 100 & 50 & 50 \\
Bodrex & 60 & 36 & 72 & 60 & 72 & 60 \\
Paramex & 200 & 350 & 350 & 450 & 250 & 250 \\
Oskadon & 150 & 50 & 100 & 100 & 250 & 150 \\
Stopcold & 25 & 25 & 50 & 25 & 50 & 25 \\
Mixagrip & 50 & 125 & 100 & 100 & 125 & 50 \\
Neozep & 25 & 50 & 50 & 50 & 50 & 50 \\
Decolgen & 50 & 25 & 25 & 75 & 75 & 50 \\
Decolsin & 50 & 50 & 50 & 50 & 50 & 25 \\
Intunal & 25 & 50 & 25 & 100 & 25 & 25 \\
Ultraflu & 50 & 125 & 100 & 100 & 50 & 50 \\
\hline
\end{tabular}

Pada Gambar 2 di bawah ini Menjelaskan alur Pelanggan memesan barang kepada Asisten Apoteker dan menerima pesanan serta membuat catatan pesanan barang dan membrikan catatan pesanan barang untuk diserahkan pada bagian gudang. Gudang mengecek stok barang dan memberikan barang ke Asisten Apoteker. data penjualan dan nota penjualan diolah Oleh Asisten Apoteker kemudian membuat laporan penjualan. Pelanggan menerima nota dan pesanan barang, Asisten Apoteker menghitung ramalan penjualan berdasrkan Metode Exponential Smoothing dibulan yang akan datang. Laporan penjualan dan peramalan yang sesuai di serahkan kepada Apoteker dan diarspikan

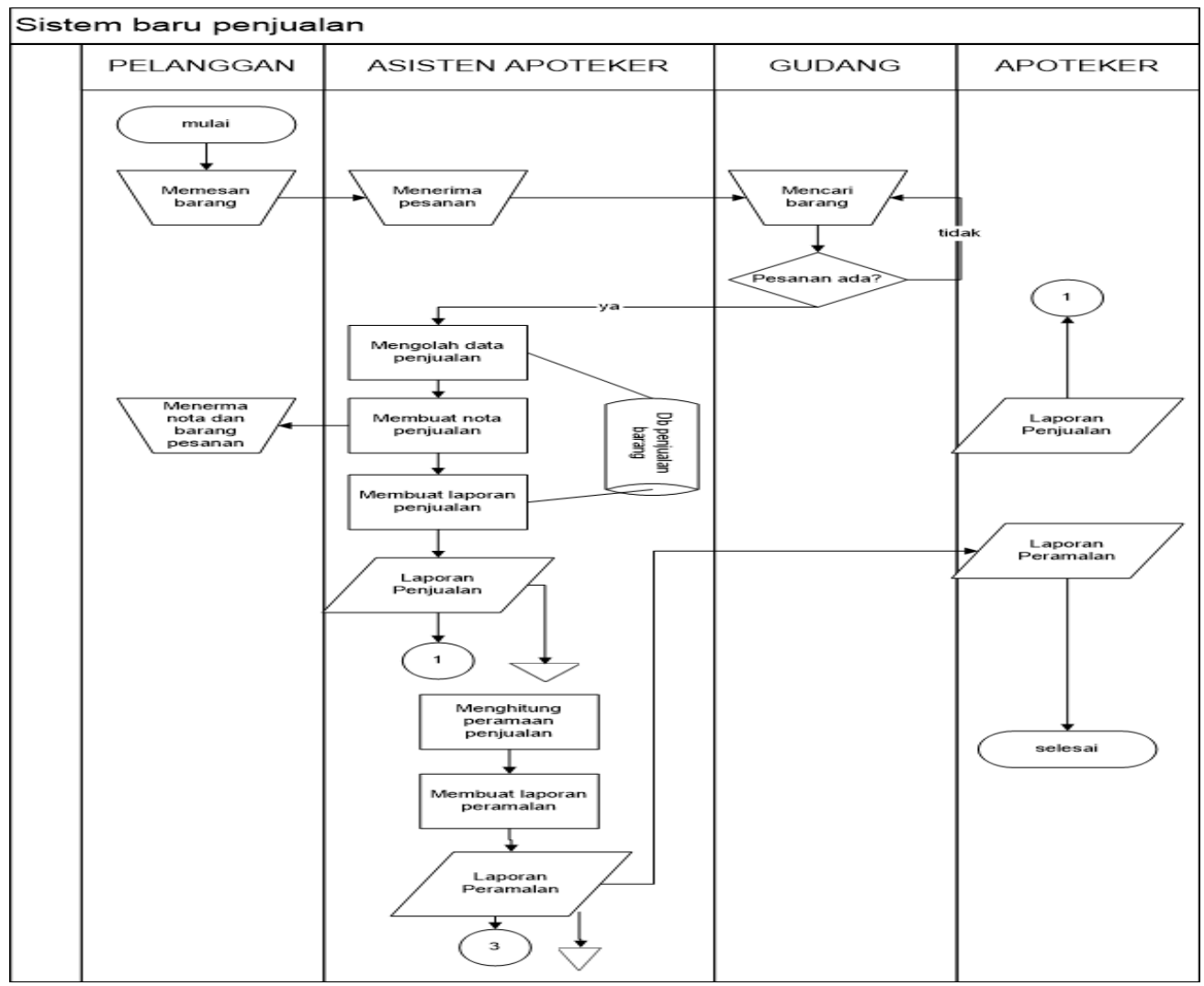

Gambar 2. Rancangan Flowchart Sistem Penjualan dengan Peramalan

Alur data berawal dari setiap data masuk yang telah diintegrasikan dengan sistem penjualan pembelian untuk mendapatkan jumlah penjualan setiap bulan. Data tersebut bertujuan pengambilan sample data time series untuk mendapatkan data uji setiap 6 bulan sebagai data awal untuk peramalan 3 bulan kedepan 


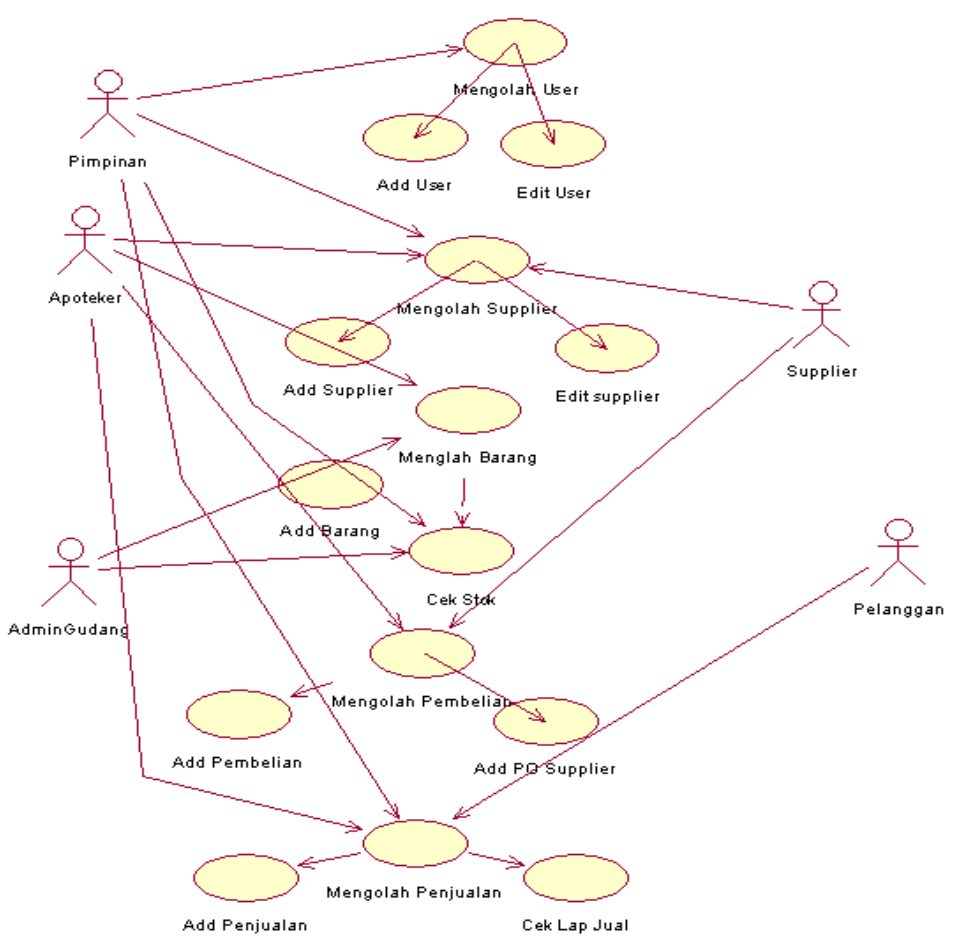

Gambar 3. Rancangan Use Case Diagram Sistem

\subsection{Implementasi Program}

Implementasi sistem dimulai dari beberapa alur dari desain sistem, desain visual aplikasi, dan pengujian aplikasi. Pada form di bawah ini merupakan tampilan dari form peramalan.

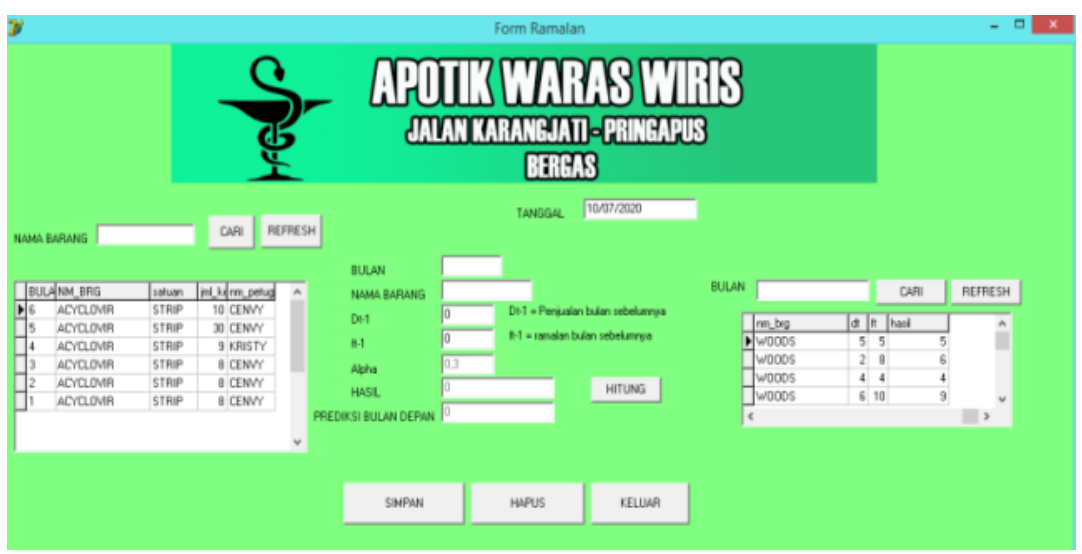

Gambar 4. Tampilan Form Peramalan.

Pada proses ini akan menjalankan perintah dengan percobaan Alpha 0.4 pada data Bodrex terdapat data series 60, 36, 72, 60, 72, 60. Percobaan ini mendapatkan Menghasilkan RMSE 14.1736 dan Rata-Rata sebesar 58.04 didapatkan tabel sebagai berikut :

Tabel 2. Tabel Percobaan dengan aplikasi menggunakan Alpha 0.4

\begin{tabular}{ccc}
\hline No & Actual & ES 0,4 \\
\hline 1 & 60 & 56,00 \\
2 & 36 & 57,60 \\
3 & 72 & 48,96 \\
4 & 60 & 58,17 \\
5 & 72 & 58,90 \\
6 & 60 & 64,14 \\
7 & & 62,48 \\
\hline
\end{tabular}


JURNAL MEDIA INFORMATIKA BUDIDARMA

Volume 5, Nomor 2, April 2021, Page 756-761

ISSN 2614-5278 (media cetak), ISSN 2548-8368 (media online)

Available Online at https://ejurnal.stmik-budidarma.ac.id/index.php/mib DOI 10.30865/mib.v5i2.2951

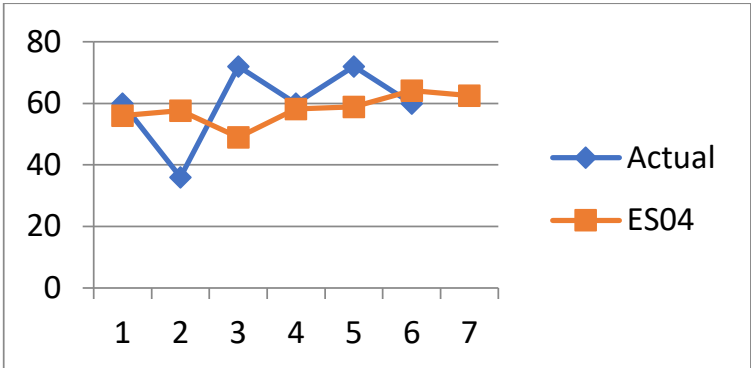

Gambar 5. Grafik perbandingan data Aktual dengan ES Alpha 0.4

Maka dengan peramalan Exponential Smoothing didapatkan 56, 57.6, 48.96, 58.17, 58.90, 64.14, 62.48. Mendapatkan RMSE 13.66959 maka dengan hasil pada tabel sebagai berikut:

Tabel 3. Tabel Percobaan dengan aplikasi menggunakan Alpha 0.3

\begin{tabular}{ccc}
\hline No & Actual & ES 0,3 \\
\hline 1 & 60 & 56,00 \\
2 & 36 & 57,20 \\
3 & 72 & 50,84 \\
4 & 60 & 57,19 \\
5 & 72 & 58,03 \\
6 & 60 & 62,22 \\
7 & & 61,56 \\
\hline
\end{tabular}

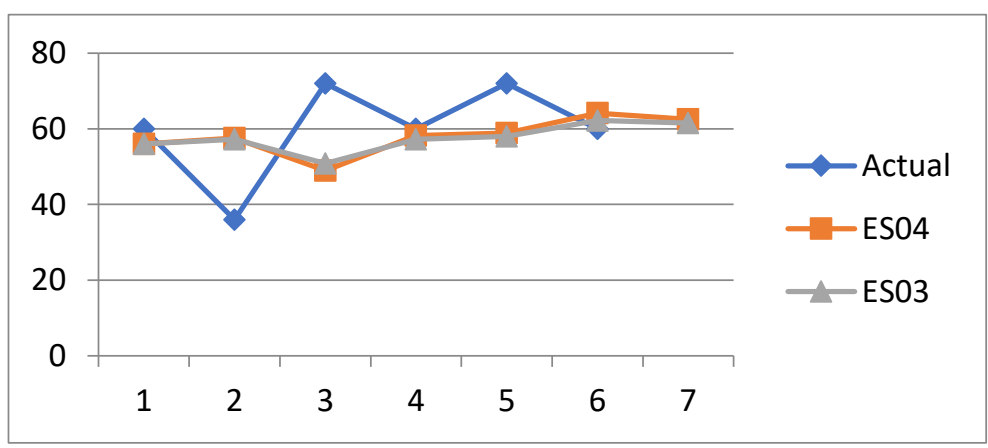

Gambar 6. Perbandingan Alpha 0,3 dan 0,4

Form perhitungan peramalan mengambil data dari form penjualan, form barang. Form ini menghitung peramalan penjualan di bulan yang akan datang

\begin{tabular}{|lllll|}
\hline LAPORAN PERHIUNGAN PERAMALAN \\
Hasil peramalan \\
bulan lalu \\
BULAN \\
1
\end{tabular}

Gambar 7. Laporan Peramalan penjualan.

\section{KESIMPULAN}

Pengujian pada aplikasi yang menerapkan metode Exponential Smoothing dengan pengujian beberapa faktor penggunaan Alpha berbeda. Ditemukan bahwa penggunaan Alpha dengan 0,3 mendekati nilai kenyataan pada penjualan. Penggunaan time series dapat dilakukan apabila jarak antar data bulan atau perubahan data tidak terlalu jauh. Penggunaan algoritma pada Exponential smoothing cukup mudah digunakan untuk peramalan yang bersifat 
urut dan dapat digunakan untuk peramalan sejauh 1 sampai 3 bulan berikutnya. Apabila pengujian sampai bulan ke 4 dan seterusnya terdapat perubahan data yang kurang mendekati kenyataan. Maka dapat diambil simpulan dari penelitian ini diambil data sample sampai peramalan bulan ke tiga untuk mendapatkan data nyata. Peramalan ini berkontribusi dengan adanya sample data percobaan dapat menganalisa bagian obat mana saja yang akan mendekati stok limit untuk membantu pemesanan kembali supaya terhindar dari kekurangan stok.

\section{REFERENCES}

[1] Ferawati, K. Davita Fersiartha, and I. Yuliana, "Analisis Pengaruh Persediaan Barang Dan Penjualan Terhadap Laba Perusahaan (Studi Kasus Cv Davin Jaya Karimun)," J. Cafe., vol. 1, no. 2, pp. 33-44, 2020, doi: 10.51742/akuntansi.v1i2.146.

[2] S. Zalukhu and I. Handriani, “Aplikasi Sistem Inventory (Studi Kasus : Pt . Cakra Medika Utama),” JSAI, Vol. 2 Nomor 1, Januari 2019, vol. 2, no. 1, pp. 116-122, 2019.

[3] V. A. Pradana and R. R. Jakaria, "Pengendalian Persediaan Bahan Baku Menggunakan," Bina Tek., vol. 16, no. 1, pp. 914, 2020.

[4] A. S. D. Rini Septiani Sukanda, "Tinjauan Atas Pengelolaan Persediaan Bahan Baku Pada Divisi Kendaraan Khusus PT. Pindad (Persero) Kota Bandung," J. Ris. Akunt. / Vol X/No.1 / April 2018, vol. X, no. 1, 2018.

[5] A. Raharja, W. Angraeni, and R. Aulia Vinarti, "Penerapan Metode Exponential Smoothing Untuk Peramalan Penggunaan Waktu Telepon Di PT.Telkomsel Divre 3 Surabaya," J. Sist. Inf., vol. 59, p. 73, 2017.

[6] L. Ni, S. Wiwik, R. Ginantra, I. Bagus, and G. Anandita, "Penerapan Metode Single Exponential Smoothing Dalam Peramalan Penjualan Barang," J. Sains Komput. Inform. Vol. 3 Nomor 2 Sept. 2019, pp. 433-441 ISSN25489771/EISSN2549-7200, vol. 3, no. September, pp. 433-441, 2019.

[7] S. Fachrurrazi, "Menggunakan Metode Single Exponential Smoothing pada Toko Obat Bintang Geurugok," 20 Techsi Vol. 6 No. 1, April 2015, vol. 7, no. 1, pp. 19-30, 2015.

[8] S. A. Faisol, "Penerapan Metode Exponential Smoothing Untuk Peramalan Jumlah Klaim Di BPJS Kesehatan Pamekasan," J. Mat. "MANTIK” Ed. Oktober 2016. Vol. 02 No. 01. ISSN 2527-3159. E-ISSN 2527-3167, vol. 02, no. 01, 2016, [Online]. Available: https://www.researchgate.net/publication/310316155_PENERAPAN_METODE_EXPONENTIAL_SMOOTHING_U NTUK_PERAMALAN_JUMLAH_KLAIM_DI_BPJS_KESEHATAN_PAMEKASAN.

[9] N. H. A. S. Al Ihsan, H. H. Dzakiyah, and F. Liantoni, "Perbandingan Metode Single Exponential Smoothing dan Metode Holt untuk Prediksi Kasus COVID-19 di Indonesia," Ultim. J. Tek. Inform., vol. 12, no. 2, pp. 89-94, 2020, doi: 10.31937/ti.v12i2.1689.

[10] A. M. Al'afi, W. Widiart, D. Kurniasari, and M. Usman, "Peramalan Data Time Series Seasonal Menggunakan Metode Analisis Spektral,” J. Siger Mat., vol. 1, no. 1, pp. 10-15, 2020, doi: 10.23960/jsm.v1i1.2484.

[11] Prof. Dr. Sugiyono, Metode Penelitian Kombinasi (Mixed Metods). Bandung: Alfabeta., 2012.

[12] N. P. L. Santiari and I. G. S. Rahayuda, "Penerapan Metode Exponential Smoothing Untuk Peramalan Penjualan Pada Toko Gitar," JOINTECS (Journal Inf. Technol. Comput. Sci., vol. 5, no. 3, p. 203, 2020, doi: 10.31328/jointecs.v5i3.1520.

[13] S. R. Albert Stephano, Shantika Martha, "Sistem Informasi Peramalan Tren Pelanggan Dengan Menggunakan Metode Double Exponential Smoothing Di Mess Gm," Coding J. Komput. dan Apl., vol. 08, no. Vol 8, No 1 (2020): Coding: $\begin{array}{lllll}\text { Jurnal Komputer dan } & \text { Aplikasi, 2020, Available: }\end{array}$ http://jurnal.untan.ac.id/index.php/jcskommipa/article/view/39767.

[14] A. ELVARITA, T. Iriani, and S. S. Handoyo, "Pengembangan Bahan Ajar Mekanika Tanah Berbasis E-Modul Pada Program Studi Pendidikan Teknik Bangunan, Universitas Negeri Jakarta,” J. PenSil, vol. 9, no. 1, pp. 1-7, 2020, doi: 10.21009/jpensil.v9i1.11987.

[15] M. Sari, "NATURAL SCIENCE : Jurnal Penelitian Bidang IPA dan Pendidikan IPA, ISSN : 2715-470X ( Online ), 2477 - 6181 ( Cetak ) Penelitian Kepustakaan ( Library Research ) dalam Penelitian Pendidikan IPA,” Nat. Sci. J. Penelit. Bid. IPA dan Pendidik. IPA, vol. 6, no. 1, pp. 41-53, 2020.

[16] S. Sofiana, S. Suparti, A. R. Hakim, and I. Triutami, "Peramalan Jumlah Penumpang Pesawat Di Bandara Internasional Ahmad Yani Dengan Metode Holt Winter'S Exponential Smoothing Dan Metode Exponential Emoothing Event Based,' J. Gaussian, vol. 9, no. 4, pp. 535-545, 2020, doi: 10.14710/j.gauss.v9i4.29448.

[17] A. Purwanto and S. N. Afiyah, "Sistem Peramalan Produksi Jagung Provinsi Jawa Barat Menggunakan Metode Double Exponential Smoothing,” J. Ilm. Teknol. Inf. Asia, vol. 14, no. 2, p. 85, 2020, doi: 10.32815/jitika.v14i2.462. 